\title{
Effects of using Flunixin Meglumine, Metamizole, and Phenylbutazone on equine kidney functions, urinary mucus, and secretory Immunoglobulin A ( $\lg A)$ concentrations
}

\author{
Mohammed I. Adam ${ }^{1,2}$, Gábor Köllerl', Corinna Arnold' and Gerald F. Schusser ${ }^{1}$ \\ 1 Department of Large Animal Medicine, Faculty of Veterinary Medicine, University of Leipzig, An den Tierkliniken 11 , 04103 Leipzig, Germany. \\ 2 Department of Medicine, Faculty of Veterinary Medicine, University of Khartoum, 13314 Khartoum North, Sudan.
}

\begin{abstract}
Summary: Nonsteroidal anti-inflammatory drugs (NSAIDs) are routinely used in equine practices to manage inflammation, endotoxemia, pain or fever in horses. This study was carried out to investigate the effects of the most commonly used nonsteroidal anti-inflammatory drugs on urinary parameters, mucus and immunoglobulin A $(\lg A)$ concentrations in horses. Thirty healthy horses (control group) and 20 horses with indications of using either flunixin meglumine (FM), metamizole or phenylbutazone (PHZ) have been used and assigned to group 1 , 2 or 3, respectively. Serum creatinine, blood urea nitrogen and electrolytes, in addition to urinary creatinine (U-Cr), urine urea nitrogen and urinary electrolytes, were measured using an automatic analyser. Fractional excretions (FE) of sodium, chloride, potassium, calcium, magnesium and inorganic phosphate, in addition to urinary protein (U-Pro): $U-C r$ and urinary gamma glutamyl transferase (U-GGT): $U-C r$ ratios were calculated. Urinary mucus and IgA concentrations and their ratios to the urinary creatinine were measured. The FEMg was significantly higher in group $3(P<0.033)$ than the control group. The U-GGT:U-Cr ratio was also significantly increased in group 3 $(P<0.001)$ compared with the control group. The U-Pro: $U-C r$ ratio was significantly higher in groups 1 and $2(P<0.007$ and $P<0.001$, respectively) than in the control group. Phenylbutazone $(\mathrm{PHZ})$ had a significantly increased mucus: $U-C r$ ratio $(\mathrm{P}<0.005)$. Significant increases were observed regarding the IgA: $U-C r$ ratio in groups $1(P<0.007)$ and $2(P<0.014)$. In conclusion, long-term use of PHZ has an influence on the renal ascending limb of the loop of Henle, and all these drugs could have effects on the proximal tubules. Phenylbutazone causes an increase in urinary mucus secretion, probably as a protective mechanism against the necrotic effect of PHZ. Parameters such as U-Pro:U-Cr and U-GGT:U-Cr ratios and FEMg are helpful in detecting these renal abnormalities.
\end{abstract}

Keywords: flunixin meglumine, metamizole, phenylbutazone, kidney function, urinary mucus, immunoglobulin $A$ (lgA), horse, equine

Citation: Adam M. I., Köller G., Arnold C., Schusser G. F. (2017) Effects of Using Flunixin Meglumine, Metamizole and Phenylbutazone on Equine Kidney Functions, Urinary Mucus, and Secretory Immunoglobulin A (IgA) Concentrations. Pferdeheilkunde 33, 263-270; DOI 10.21836/PEM20170307

Correspondence: Prof. Gerald F. Schusser, University of Leipzig, Department of Large Animal Medicine, An den Tierkliniken 11,045103 Leipzig; e-mail: schusser@vetmed.uni-leipzig.de.

\section{Introduction}

Nonsteroidal anti-inflammatory drugs (NSAIDs) are routinely used in equine practices to manage inflammation, endotoxemia, pain or fever in horses (Cook and Blikslager 2015). However, NSAIDs have been reported to have many side effects in horses (MacAllister et al. 1993), human beings (Harirforoosh and Jamali 2009), dogs (Kukanich et al. 2012) and cats (Lascelles et al. 2007). In horses, the gastrointestinal (Gl) tract and kidneys are considered the organs most affected by the side effects of NSAIDs. The mechanism of action of NSAIDs involves the inhibition of cyclooxygenases (COX), mainly COX-1 and COX-2. These enzymes are responsible for synthesizing prostanoids, which are important to prevent $\mathrm{Gl}$ tract ulcers, enhance $\mathrm{Gl}$ tract mucosal repair, and control and maintain $\mathrm{Gl}$ tract and renal blood flow to correct hypovolaemia (Tomlinson and Blikslager 2004, McConnico et al. 2008, Cook and Blikslager 2015). The side effects of NSAIDs in the $\mathrm{Gl}$ tract include $\mathrm{Gl}$ ulceration, right dorsal colitis, and diarrhoea in foals (McConnico et al. 2008, Cook and Blikslager 2015). On the other hand, flunixin meglumine (FM) supports the recovery of the colonic mucosa in the ischemic segment of the large colon (Matyjaszek et al. 2009). Although several studies have been conducted to investigate the adverse effects of NSAIDs on horses, only a few reports have described their effects on the equine urinary system, probably because they happen rarely under recommended doses and are associated mainly with hypovolaemia. Horses have the potential to develop renal papillary necrosis if they are treated with overdoses of phenylbutazone (PHZ) or, to a lesser extent, FM (MacAllister et al. 1993), or when they are treated with $\mathrm{PHZ}$ and are deprived of water (Gunson and Soma 1983). Side effects that have been reported after using metamizole (MZ) in human and veterinary medicine include mild GI tract disorders, aplastic anaemia, skin allergy and renal dysfunctions (Jasiecke et al. 2014, Bentz 2015). Diagnostically, urinary parameters, such as urinary gamma glutamyl transferase:urinary creatinine ratio (U-GGT:U-Cr) and fractional excretion of sodium (FENa), can be used to detect the effect of PHZ on the kidney function (El-Ashker et al. 2012). The urinary tract is systemically and ascendingly exposed to the pathogens, however, urinary mucus and immunoglobulin $A$ $(\lg A)$ play an important role in protecting the urinary tract. The mucus layer of mucous membranes is a sufficient defence mechanism to prevent adhesion of bacteria to the epithelial cells and clear them from the system (Hansson 2012). Previous studies have shown that urinary tract infections (UTIs) in horses are associated with lesions which interfere with urine 
flow or can cause urinary mucosal damage (Saulez et al. 2005, Squinas and Britton 2013). Recent reports have indicated different information regarding the ability of $\mathrm{PHZ}$ to affect the protective mechanisms of the urinary system: while one report has shown that long-term use of $\mathrm{PHZ}$ can cause ulcerative cystitis in horses, presumably by reducing prostaglandins (Aleman et al. 2011), another study has reported that using PHZ for seven days has no effect on COX-1 and COX2 expression in bladder mucosa (Nieto et al. 2012). In a study performed on children's urine, it has been found that secretory IgA concentration increased in individuals with UTIs and can be used as a marker to identify types of UTIs (Deo and Vaidya 2004). As NSAIDs are used commonly in equine practices and little is known about their effects on the urinary defence mechanisms, accordingly, the objective of the present study was to investigate the influences of using FM, MZ and $\mathrm{PHZ}$ on different equine urinary parameters, urinary mucus and $\lg A$ concentrations in horses.

\section{Materials and Methods}

\section{Animals and Study Design}

Thirty horses, 19 females, 1 male and 10 geldings, of different breeds (21 Warmbloods, 3 Arabians, 2 ponies, 1 quarter horse, 1 Friesian, 1 Icelandic horse and 1 draft horse), ranging between 2 and 24 years (median 18.5 years) in age, and between 150 and $681 \mathrm{~kg}$ (median $524.5 \mathrm{~kg}$ ) in weight, were used as a control group to determine the normal haematological, serum biochemical and urinary values, and normal urinary mucus and $\lg \mathrm{A}$ concentrations. These horses were included in this group based on their normal clinical and clinicopathological examinations. Some of these horses were teaching herd horses. The remaining horses were clientowned and presented to the clinic for soundness examinations. They were kept in straw-bedded boxes, and were provided with hay $(1.5 \mathrm{~kg} / 100 \mathrm{~kg} \mathrm{BW} / \mathrm{d})$ and concentrate $(0.2 \mathrm{~kg} / 100 \mathrm{~kg} \mathrm{BW} / \mathrm{d})$ twice daily and water ad libitum. The sick horses were admitted to the Department of Large Animal Medicine, Faculty of Veterinary Medicine, University of Leipzig, Germany, between April 2015 and July 2016. All horses were diagnosed and treated. In addition to the control group, 20 horses were treated with NSAIDs, and, depending on the type of NSAIDs used, were assigned to one of the following groups: Horses with left dorsal colon displacement were treated with FM in group 1 ( $n=9$ horses). According to the intravascular volume deficit colic horses were rehydrated with lactated ringer's solution within 30 to 60 minutes. The calculation of the intravascular volume deficit was done based on the formula: [(patient's PCV in \% minus normal PCV) divided by normal PCV in \%)] multiply with $100=$ percentage of intravascular volume deficit. The continuous fluid treatment was done with 50 to $75 \mathrm{ml} / \mathrm{kg}$ BW/d i.v. using lactated ringer's solution and feed and water were withheld. All these horses had normal rectal findings at the end of the second day of treatment. After that time, horses had water ad libitum, were fed a small amount of hay three times a day and received no more fluid treatment, but still FM (q12 hr) treatment until day 3 after admission. Two horses of this group were excluded because they were also treated with i.v. fluids during the third day. Horses with left ventral large colon impaction were treated with $M Z$ and assigned to group 2 ( $n=6$ horses). These horses were treated with isotonic sodium sulphate (1.8\%; $20 \mathrm{~mL} / \mathrm{kg} \mathrm{BW} / \mathrm{d}$ ) orally via nasogastric tube and the impaction was resolved within $48 \mathrm{~h}$. During treatment, the horses had water ad libitum and the feed was withheld. After resolving, the horses received a small amount of hay four times a day and were still treated with $M Z$ until day three. Group 3 included horses with lameness grade 1/5 and were administered $\mathrm{PHZ}$ for three to five days ( $n=7$ horses). All the patients were treated with either FM $(1.1 \mathrm{mg} / \mathrm{kg}$ BW, i.v., Q12h. for 3 days; Finadyne ${ }^{\circledR}, M S D$, Germany), $M Z$ $\left(40 \mathrm{mg} / \mathrm{kg} \mathrm{BW}\right.$, i.v., Q12h. for 3 days; Metapyrin ${ }^{\circledR}$, Serumwerk Bernburg AG, Germany) or PHZ (4.4 mg/kg BW, p.o., Q24 h. for 3 to 5 days; Butasan ${ }^{\circledR}$, Selectavet Dr. Otto Fischer $\mathrm{GmbH}, \mathrm{Germany})$. All horses of all groups had no cardiovascular and/or renal disorders. The colic horses and lame horses did not receive any treatment before admission at the university animal hospital. The Animal Welfare Commission gave the ethical approval (W 06/16).

\section{Blood and Urine Samples}

Both blood and urine samples were collected from the horses of group 1 and 2 at the same time on the third day of treatment, and from the horses of group 3 on day three to five of treatment. Samples from the control group were collected on day two of hospitalisation. All samples were collected in the morning. Blood and serum samples were collected in $4 \mathrm{~mL}$ ethylenediaminetetraacetic acid and $10 \mathrm{~mL}$ plain tubes, respectively, from the jugular vein. Complete blood count was performed immediately on blood samples using the haematological analyser ADVIA 120 (Siemens Healthcare Diagnostics, Dreieich, Germany). Serum samples were centrifuged at $1100 \mathrm{~g}$ for 10 minutes at $4{ }^{\circ} \mathrm{C}$, then stored at $-20^{\circ} \mathrm{C}$ until further analysis. The whole amount of urine was collected from female patients using a $50 \mathrm{~cm}$ long plastic urethral catheter as described by Schaer and Orsini (2014). The urin samples of stallions and geldings were collected using a collecting bag, which was placed on the horse's waist until the horse urinated, then transferred into collecting tube immediately.

\section{Renal Function}

In this experiment, analyses of serum electrolytes ( $\mathrm{Na}, \mathrm{Cl}, \mathrm{K}$, $\mathrm{Mg}, \mathrm{Ca}, \mathrm{iP})$, blood urea nitrogen (BUN), serum creatinine ( $\mathrm{S}$ $\mathrm{Cr}$ ), serum glucose (S-Glu) and serum total protein (S-Prot) were performed. Urinary $\mathrm{pH}$ was measured with a $\mathrm{pH}$ electrode and specific gravity was measured using an araeometer for each urine sample within 30 minutes of collection. The rest of the urine samples were centrifuged at $500 \mathrm{~g}$ for $5 \mathrm{~min}$ at $4{ }^{\circ} \mathrm{C}$ and stored at $-20^{\circ} \mathrm{C}$ until further analysis of urinary electrolytes ( $\mathrm{Na}, \mathrm{Cl}, \mathrm{K}$, and $\mathrm{Mg}$ ), urinary urea nitrogen ( $\mathrm{U}$ $\mathrm{UN})$, urinary creatinine ( $\mathrm{U}-\mathrm{Cr}$ ), urinary glucose (U-Glu), urinary protein (U-Prot) and urinary gamma glutamyl transferase (U-GGT). In order to obtain an accurate measurement of the $\mathrm{Ca}$ and $\mathrm{Pi}$ in the urine, one aliquot of each urine sample was mixed with acetic acid for $30 \mathrm{~min}$ to solubilize calcium carbonate, calcium phosphate and calcium oxalate crystals (Schott 2010) before the Ca and iP concentrations were measured. Both serum and urinary parameters were measured using the automatic analyser Hitachi 912 (Roche Diagnostics, GmbH, Mannheim, Germany). The reagents for the automatic analy- 
ser were purchased from Roche Diagnostics and Randox (Randox Ltd., Krefeld, Germany). All of the haematological and serum and urinary biochemical values were expressed using the International System of Units; furthermore, the UGGT:U-Cr ratio in IU/mmol, U-Cr:S-Cr ratio in $\mu \mathrm{mol} / \mu \mathrm{mol}$, U-Pro: $U$-Cr ratio in $\mathrm{g} / \mathrm{mmol}$, UUN:BUN ratio in $\mathrm{mmol} / \mathrm{mmol}$, and fractional excretions (FE) of $\mathrm{Na}, \mathrm{Cl}, \mathrm{K}, \mathrm{Mg}$, inorganic Phosphate (iP) and $\mathrm{Ca}$ were calculated in percentage. The FE of electrolytes was calculated using the following equation:

$$
\mathrm{FE}_{\mathrm{x}}=\frac{\mathrm{S}-\mathrm{Cr} \times \text { electrolyte concentration in urine }}{\mathrm{U}-\mathrm{Cr} \times \text { electrolyte concentration in serum }} \times 100
$$

\section{Urinary Mucus and IgA Measurements}

The urinary mucus concentration was measured using a modified version of the method of Biörnsson (1993, 1998). The dye solution was prepared by dissolving $900 \mathrm{mg}$ Alcian Blue GXa in $100 \mathrm{ml}$ of a solution that consisted of $30 \mathrm{ml} \mathrm{sul-}$ furic acid $0.5 \%$ and $5 \mathrm{ml}$ of $8 \mathrm{M}$ urea solution. An amount of $50 \mu \mathrm{l} 8 \mathrm{M}$ urea solution and $750 \mu \mathrm{l}$ of dye solution were pipetted into $50 \mu \mathrm{l}$ of each urine sample then incubated for $16 \mathrm{~h}$ in a refrigerator at $4^{\circ} \mathrm{C}$. Thereafter, the sample was centrifuged $(13,000 \times \mathrm{g}$ for $15 \mathrm{~min})$ and the supernatant was discarded. The remaining precipitate was washed with a solution consisting of $0.5 \mathrm{M} \mathrm{MgCl}_{2}$, solution in $40 \%$ dimethyl sulfoxide, centrifuged again $(13,000 \times \mathrm{g}$ for $15 \mathrm{~min})$ and the supernatant wash solution was discarded; the washing and centrifugation were repeated three times. The urine mucus-dye complex was dissolved in $500 \mu \mathrm{l}$ of a solution consisting of $4 \mathrm{M}$ urea solution/n-propanol $(2: 1 ; \mathrm{v} / \mathrm{v})$. The intensity of the resulting blue solution was measured by an ultraviolet-visible photometer (Beckman 640-DUb) at $620 \mathrm{~nm}$. In the absence of equine mucin as a reference material, porcine mucin type $\|^{a}$ was used as a standard for calibration and control (Köller et al. 2010). An amount of $200 \mu \mathrm{l}$ of urine and $200 \mu \mathrm{l}$ of $2 \mathrm{M}$ sodium hydroxide solution were heated for $4 \mathrm{~h}$ at $95^{\circ} \mathrm{C}$ for the negative control. After cooling, the mixtures were neutralized with $100 \mu$ l of sulphuric acid (10\%), then the remaining urinary mucus concentrations were measured by the same method described above. All urine samples and positive and negative controls were measured in triplicate, and the mean values were used for statistical analysis. Measurement of urinary $\lg A$ was performed using horse IgA ELISA, as described by the manufacturer ${ }^{c}$, with slight modification. Because the total urinary protein concentration is very low and the optimal $\lg A$ concentration was needed, one of the control group samples and another from a horse diagnosed with haemorrhagic cystitis were used in three different concentrations (undiluted, 1:10 and 1:100 using distilled water). Consequently, urine samples of the control group were used in an undiluted form, while samples from horses with suspected urinary tract inflammatory process were diluted at a ratio of $1: 10$. Briefly, the calibrators, diluted and undiluted samples, were added to duplicate wells in horse IgA-coated microplates, and incubated for $30 \mathrm{~min}$ at $22^{\circ} \mathrm{C}$; after aspirating the contents of the wells, the washing solution was used manually four times. Subsequently, enzymeantibody conjugated with horseradish peroxidase was added to each well and incubated in the dark at $22^{\circ} \mathrm{C}$ for 30 minutes. Afterwards, all wells were washed four times and $3,3^{\prime}, 5,5^{\prime}$-tetra-methylbenzidine substrate was added to each well; after incubation for $10 \mathrm{~min}$ in the dark, the stop solution was added to all wells. The absorbance was determined using an ELISA reader ${ }^{d}$ at $450 \mathrm{~nm}$ wavelength. As the concentrations of the urinary mucus and $\lg A$ are subject to change even in normal individuals, depending on their water consumption and temperature of the environment, the mucus: $U-C r$ in $\mathrm{g} / \mathrm{mmol}$ and urinary $\lg \mathrm{A}: \mathrm{U}-\mathrm{Cr}$ in $\mu \mathrm{g} / \mathrm{mmol}$ ratios were used.

\section{Statistical Analysis}

Statistical analyses of the data were carried out using the statistical software programme (SPSS 22, International Business Machines (IBM) cooperation, New York, USA). Data were examined for normal distribution using the Shapiro-Wilk test, which revealed that the data were not normally distributed, and their descriptive statistics were described as median, $1 \mathrm{st}$ and 3rd quartile, and because of urine iP values of some horses were under the defection limit, the minimum and maximum of $\mathrm{FE}_{\mathrm{ip}}$ were used. Differences between the control and groups treated were tested using the Kruskal-Wallis one-way analysis of variance (ANOVA) test and Dunn's method. Significance was set at $P \leq 0.05$.

\section{Results}

Renal Function

A total of 50 horses were included in this experiment, of which 20 horses were treated with FM, MZ or PHZ. Of these 20 horses, 10 were females, 9 were geldings and 1 was male; their ages ranged between 7 and 24 years (median 21 years). They were of different breeds including 11 Warmbloods, 2 Friesians, 2 Arabians, 1 Haflinger, 1 Icelandic horse, 1 pony, 1 Lewitzer and 1 Holsteiner horse. There were no differences between all groups and control group regarding age and gender. There was a significant difference

Table 1 Clinical and haematological findings of the healthy horses (control group) and groups treated (group 1: horses treated with flunixil meglumine for three days; group 2: horses treated with metamizole for three days; group 3: horses treated with phenylbutazone for three to fivi days). The results are described as median, $\left(1^{\text {st }}\right.$ to $3^{\text {rd }}$ quartile). Temp., rectal temperature; RBCs, red blood corpuscles; PCV, packet cell volume WBCs, white blood cells; $n$, number of horses in each group. *Significantly different values compared with those of the control group.

\begin{tabular}{cccccc}
\hline Variables & $\begin{array}{c}\text { Normal range } \\
\text { of all breeds }\end{array}$ & $\begin{array}{c}\text { Control group } \\
(\mathrm{n}=30)\end{array}$ & $\begin{array}{c}\text { Group } 1(\mathrm{n}=7) \\
\text { Flunixin meglumine }\end{array}$ & $\begin{array}{c}\text { Group } 2(\mathrm{n}=6) \\
\text { Metamizole }\end{array}$ & $\begin{array}{c}\text { Group } 3(\mathrm{n}=7) \\
\text { Phenylbutazone }\end{array}$ \\
\hline Temp. $\left({ }^{\circ} \mathrm{C}\right)$ & $37.5-38.0$ & $37.6(37.4-37.9)$ & $38(37.6-38.9)^{*}$ & $38.4(37.2-38.9)$ & $37.5(37.3-37.7)$ \\
RBCs $\left(\times 10^{12} / \mathrm{L}\right)$ & $5.1-11.9^{(1)}$ & $7.4(7.0-8.1)$ & $7.1(6.5-7.2)$ & $6.2(5.9-7.2)^{*}$ & $6.67(6.23-7.24)^{*}$ \\
PCV $(\mathrm{L} / \mathrm{L})$ & $0.22-0.39^{(1)}$ & $0.34(0.31-0.36)$ & $0.31(0.29-0.31)^{*}$ & $0.31(0.29-0.33)^{*}$ & $0.32(0.28-0.32)$ \\
WBCs $\left(\times 10^{9} / \mathrm{L}\right)$ & $4.4-16.5^{(1)}$ & $7.1(6.0-9.7)$ & $7.9(6.4-9.7)$ & $8.6(6.9-10.3)$ & $7(6.1-9.3)$ \\
\hline
\end{tabular}

(1) Köller et al. 2014 
Table 2 Serum biochemical parameters of the healthy horses (control group) and groups treated (group 1: horses treated with flunixin meglumine for three days; group 2: horses treated with metamizole for three days; group 3: horses treated with phenylbutazone for three to five days). The results are described as median, $\left(1^{\text {st }}\right.$ to $3^{\text {rd }}$ quartile). Pi, inorganic phosphate; $\mathrm{S}-\mathrm{Cr}$, serum creatinine; BUN, blood urea nitrogen; *Significantly different values compared with those of control group.

\begin{tabular}{lccccc}
\hline \multicolumn{1}{c}{ Variables } & $\begin{array}{c}\text { Normal range } \\
\text { of all breeds }\end{array}$ & $\begin{array}{c}\text { Control group } \\
(\mathrm{n}=30)\end{array}$ & $\begin{array}{c}\text { Group } 1(\mathrm{n}=7) \\
\text { Flunixin meglumine }\end{array}$ & $\begin{array}{c}\text { Group 2 }(\mathrm{n}=6) \\
\text { Metamizole }\end{array}$ & $\begin{array}{c}\text { Group 3 }(\mathrm{n}=7) \\
\text { Phenylbutazone }\end{array}$ \\
\hline $\mathrm{Na}(\mathrm{mmol} / \mathrm{L})$ & $134-135$ & $138(136-140)$ & $139(137-139)$ & $139(137-141)$ & $139(138-140)$ \\
$\mathrm{Cl}(\mathrm{mmol} / \mathrm{L})$ & $88.8-114.6$ & $100(96.5-101.2)$ & $99.6(95.2-101.6)$ & $98.9(95.1-103.9)$ & $100.7(97.1-103.6)$ \\
$\mathrm{K}(\mathrm{mmol} / \mathrm{L})$ & $2.0-4.8$ & $3.7(3.4-4.2)$ & $3.8(3.60-3.98)$ & $3.6(3.2-3.7)$ & $3.93(3.4-4.2)$ \\
$\mathrm{Ca}(\mathrm{mmol} / \mathrm{L})$ & $2.62-3.23$ & $3.1(2.8-3.2)$ & $2.99(2.83-3.10)$ & $3(2.7-3.2)$ & $3.1(2.9-3.4)$ \\
$\mathrm{Pi}(\mathrm{mmol} / \mathrm{L})$ & $0.42-3.03$ & $0.97(0.84-1.10)$ & $0.88(0.76-1.04)$ & $0.82(0.77-0.91)$ & $0.8(0.7-1.5)$ \\
$\mathrm{Mg}(\mathrm{mmol} / \mathrm{L})$ & $0.61-0.98$ & $0.67(0.64-0.74)$ & $0.61(0.56-0.71)$ & $0.63(0.60-0.66)^{*}$ & $0.66(0.63-0.67)$ \\
$\mathrm{S}-\mathrm{Cr}(\mu \mathrm{mol} / \mathrm{L})$ & $51.0-156.4$ & $106(87-115)$ & $115(103-133)$ & $99.5(93-128)$ & $112(98-127)$ \\
$\mathrm{BUN}(\mathrm{mmol} / \mathrm{L})$ & $1.22-8.95$ & $4.4(4.0-5.8)$ & $4.8(2.6-5.4)$ & $4.5(3.70-5.35)$ & $4.75(4.6-6.4)$ \\
Glucose $(\mathrm{mmol} / \mathrm{L})$ & $2.18-9.17$ & $5.9(5.1-6.5)$ & $5.7(4.90-6.99)$ & $5.2(4.5-6.3)$ & $5.14(4.50-5.43)$ \\
Total protein & $48.0-81.4$ & $64.3(61.1-70.0)$ & $63.1(44.3-70.2)$ & $65.95(54.9-70.0)$ & $60.4(59.4-66.8)$ \\
\hline
\end{tabular}

(2) Köller et al. 2014

Table 3 Urinary parameters of healthy horses (control group) and groups treated (group 1: horses treated with flunixin meglumine for three days; group 2: horses treated with metamizole for three days; group 3: horses treated with phenylbutazone for three to five days). The results are described

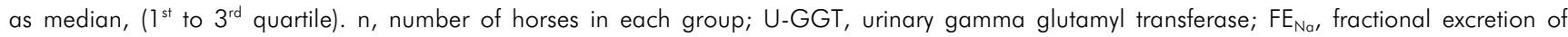
sodium; $\mathrm{FE}_{\mathrm{Cl}}$, fractional excretion of chloride: $\mathrm{FE}_{\mathrm{K}}$, fractional excretion of potassium; $\mathrm{FE}_{\mathrm{Ca}}$, fractional excretion of calcium; $\mathrm{FE}_{\mathrm{ip}}$, fractional excretion of inorganic phosphate; $\mathrm{FE}_{\mathrm{Mg}}$, fractional excretion of magnesium; U-GGT:U-Cr, urinary gamma glutamyl transferase:urinary creatinine ratio; U-Cr:S$\mathrm{Cr}$, urinary creatinine:serum creatinine ratio; U-Pro:U-Cr, urinary protein:urinary creatinine ratio; UUN:BUN, urinary urea nitrogen:serum blood urea nitrogen ratio; $\mathrm{FE}_{\mathrm{ip}}$ expressed as minimum and maximum values as some iP in some horses was below the detectable limit; NA, not available: Urinary GGT in some horses of group 1 was below the detectable limit. *Significantly different values compared with those of control group.

\begin{tabular}{|c|c|c|c|c|c|}
\hline Variables & $\begin{array}{l}\text { Normal range for all } \\
\text { breeds }\end{array}$ & $\begin{array}{l}\text { Control group }(\mathrm{n}= \\
\qquad 30)\end{array}$ & $\begin{array}{c}\text { Group } 1(n=7) \\
\text { Flunixin meglumine }\end{array}$ & $\begin{array}{l}\text { Group } 2(\mathrm{n}=6) \\
\text { Metamizole }\end{array}$ & $\begin{array}{l}\text { Group } 3(n=7) \\
\text { Phenylbutazone }\end{array}$ \\
\hline Specific gravity & $1.030-1.050$ & $\begin{array}{c}1.035 \\
(1.028-1.043)\end{array}$ & $\begin{array}{c}1.026 \\
(1.014-1.042)\end{array}$ & $\begin{array}{c}1.023 \\
(1.019-1.026)^{*}\end{array}$ & $\begin{array}{c}1.038 \\
(1.030-1.054)\end{array}$ \\
\hline $\mathrm{pH}$ & $7.6-8.4^{(3)}$ & $\begin{array}{c}7.65 \\
(7.23-8.00)\end{array}$ & $\begin{array}{c}7.94 \\
(7.63-8.10)\end{array}$ & $\begin{array}{c}7.3 \\
(7.10-7.59)\end{array}$ & $\begin{array}{c}7.53 \\
(6.92-7.90)\end{array}$ \\
\hline Glucose (mmol/L) & not available & $\begin{array}{c}0.5 \\
(0.33-0.60)\end{array}$ & $\begin{array}{c}0.37 \\
(0.17-0.42)\end{array}$ & $\begin{array}{c}0.68 \\
(0.61-0.80)^{*}\end{array}$ & $\begin{array}{c}0.6 \\
(0.30-0.65)\end{array}$ \\
\hline Protein $(g / L)$ & $<0.4^{(3)}$ & $\begin{array}{c}0.07 \\
(0.05-0.11)\end{array}$ & $\begin{array}{c}0.2 \\
(0.08-0.57)^{*}\end{array}$ & $\begin{array}{c}0.185 \\
(0.095-0.350)^{*}\end{array}$ & $\begin{array}{c}0.1 \\
(0.07-0.23)\end{array}$ \\
\hline $\mathrm{FE}_{\mathrm{Na}}(\%)$ & $0.032-0.520^{(4)}$ & $\begin{array}{c}0.052 \\
(0.035-0.072)\end{array}$ & $\begin{array}{c}0.18 \\
(0.039-0.320)^{*}\end{array}$ & $\begin{array}{c}0.03 \\
(0.029-0.036)^{*}\end{array}$ & $\begin{array}{c}0.161 \\
(0.063-1.360)^{*}\end{array}$ \\
\hline $\mathrm{FE}_{\mathrm{Cl}}(\%)$ & $0.59-1.86^{(4)}$ & $\begin{array}{c}0.76 \\
(0.47-1.02)\end{array}$ & $\begin{array}{c}0.9 \\
(0.52-0.99)\end{array}$ & $\begin{array}{c}0.31 \\
(0.18-0.58)^{*}\end{array}$ & $\begin{array}{c}0.83 \\
(0.390-0.994)\end{array}$ \\
\hline $\mathrm{FE}_{\mathrm{K}}(\%)$ & $23.3-48.1^{(4)}$ & $\begin{array}{c}39.89 \\
(26.63-48.10)\end{array}$ & $\begin{array}{c}46.29 \\
(38.80-65.32)\end{array}$ & $\begin{array}{c}19.61 \\
(11.42-28.26)^{*}\end{array}$ & $\begin{array}{c}38.85 \\
(29.84-52.60)\end{array}$ \\
\hline $\mathrm{FE}_{\mathrm{Ca}}(\%)$ & $0-6.72^{(4)}$ & $\begin{array}{c}5.37 \\
(2.46-8.60)\end{array}$ & $\begin{array}{c}6.5 \\
(3.32-12.60)\end{array}$ & $\begin{array}{c}4.6 \\
(3.99-5.05)\end{array}$ & $\begin{array}{c}15.26 \\
(3.99-42.18)^{*}\end{array}$ \\
\hline $\mathrm{FE}_{\mathrm{iP}}(\%)$ & $0->20^{(4)}$ & $0.004-3.241$ & $0.054-8.582$ & $0.066-4.142$ & $0.034-1.416$ \\
\hline $\mathrm{FE}_{\mathrm{Mg}}(\%)$ & $20.8-43-1^{(4)}$ & $\begin{array}{c}11.39 \\
(6.79-20.20)\end{array}$ & $\begin{array}{c}15.31 \\
(12.80-23.08)\end{array}$ & $\begin{array}{c}16.27 \\
(10.94-22.60)\end{array}$ & $\begin{array}{c}18.41 \\
(14.02-25.58)^{*}\end{array}$ \\
\hline $\begin{array}{c}\text { U-GGT:U-Cr } \\
\text { (U/mmol) }\end{array}$ & $<2.62^{(5)}$ & $\begin{array}{c}0.073(0.037- \\
0.200)\end{array}$ & NA & $\begin{array}{c}0.038 \\
(0.009-0.290)\end{array}$ & $\begin{array}{c}1.06 \\
(0.74-1.86)^{*}\end{array}$ \\
\hline $\begin{array}{c}\text { U-Cr:S-Cr } \\
(\mu \mathrm{mol} / \mu \mathrm{mol})\end{array}$ & $2-344^{(4)}$ & $\begin{array}{c}215.7 \\
(164.90-314.97)\end{array}$ & $\begin{array}{c}153.3 \\
(70.9-223.0)^{*}\end{array}$ & $\begin{array}{c}108.49 \\
(98.60-134.79)^{*}\end{array}$ & $\begin{array}{c}145.7 \\
(103.99-313.92)\end{array}$ \\
\hline $\begin{array}{l}\text { U-Pro:U-Cr } \\
\text { (g/mmol) }\end{array}$ & not available & $\begin{array}{c}0.003 \\
(0.002-0.006)\end{array}$ & $\begin{array}{c}0.008 \\
(0.004-0.070)^{*}\end{array}$ & $\begin{array}{c}0.014 \\
(0.009-0.028)^{*}\end{array}$ & $\begin{array}{c}0.005 \\
(0.003-0.023)\end{array}$ \\
\hline $\begin{array}{c}\text { UUN:BUN } \\
(\mathrm{mmol} / \mathrm{mmol})\end{array}$ & $20-124^{(4)}$ & $\begin{array}{c}61.05 \\
(45.5-79.9)\end{array}$ & $\begin{array}{c}45.43 \\
(26.43-62.70)\end{array}$ & $\begin{array}{c}36.4 \\
(31.3-48.6)^{*}\end{array}$ & $\begin{array}{c}42.15 \\
(31.65-52.55)\end{array}$ \\
\hline
\end{tabular}

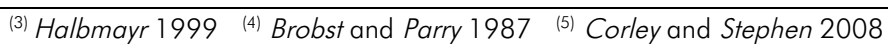


$(P<0.029)$ in the rectal temperatures of the horses in group 1 in comparison with those of the control group (Tab. 1). Haematological values, such as red blood cell (RBC) and white blood cell (WBC) counts and packed cell volume (PCV) of all groups were within normal ranges and are listed in Table 1 (Köller et al. 2014). The serum biochemical values are summarized in Table 2. Most of the serum biochemical values of the groups treated did not differ significantly from those of the control group. Serum Mg was significantly lower in group $2(P<0.045)$ compared with the control group. Urinary parameters of the control and groups treated are listed in Table 3. Urine specific gravity decreased significantly in the horses of group $2(P<0.002)$ compared with the control group. Urinary protein concentration was significantly higher in group $1(P<0.037)$ and group $2(P<0.021)$ compared with the control group. The FENa was significantly higher in group $1(P<0.018)$ and group $3(P<0.005)$, and significantly lower in group $2(P<0.017)$ in comparison with the control group. The $\mathrm{FECl}$ was significantly lower in group 2 $(P<0.02)$ when compared with the control group. Only group 2 showed a significant decrease in the FE of potassium of $P<0.008$ compared with the control group. Significant increases in the FE of calcium and magnesium were observed in group $3(P<0.02)$, $(P<0.033)$ respectively, when compared with the control group. The FEiP of the horses in all groups treated were within the normal range, as presented in Table 3. The U-GGT:U-Cr ratio was significantly higher in group $3(P<0.001)$ compared with the control group. The $U$ Pro: $U-C r$ ratio was significantly higher in group $1(\mathrm{P}<0.007)$ and group $2(P<0.001)$ than the control group. The U-Cr:SCr ratios of group $1(P<0.036)$ and $2(P<0.001)$ showed significant decreases compared with the control group. The UUN:BUN ratio was significantly lower in group $2(P<0.03)$ than the control group. Because the urinary phosphate concentration in some horses in all groups were below the detectable limit, in addition to U-GGT concentrations of some horses in group 1, their statistics could not be calculated.

\section{Urinary Mucus and $\lg A$ Concentrations}

Both urinary mucus and $\lg A$ values of the control group and groups treated were summarized as median and 1 st and $3 \mathrm{rd}$ quartile in Table 4 and 5, respectively. No influence of the methods of urine collection on the mucus concentration was found. There was a significant difference in the urinary mucus: $U-C r$ ratio of the horses in group $3(\mathrm{P}<0.005)$ compared with those in the control group, and no significant differences between the other groups and the control group or among the groups have been detected (Tab. 4). The urinary $\lg$ A concentration was significantly higher in group 2 $(P<0.022)$. Groups 2 and 3 showed a significantly increased IgA: $U-C r$ ratio ( $P<0.007$ and $P<0.014$, respectively) compared with the control group (Tab. 5). No significant differences were detected among the groups treated regarding the urinary $\lg \mathrm{A}$ concentration and the $\lg \mathrm{A}: \mathrm{U}-\mathrm{Cr}$ ratio.

\section{Discussion}

The current study describes renal function parameters in horses treated for three to five days with NSAIDs for gastrointestinal (FM, MZ) or orthopedic (PHZ) pain. Our results on equine kidney functions using $\mathrm{FM}, \mathrm{MZ}$ and $\mathrm{PHZ}$ were compared with findings in the literature (MacAllister et al. 1993, ElAshker et al. 2012). The limitation of this study is the samples were collected on days 3-5 of treatment, no samplings were performed before treatment, as these horses were patients brought to the clinic to be treated for their gastrointestinal and orthopedic conditions. Hyponatraemia is a sign of acute renal disorders, although not all horses with acute renal diseases develop hyponatraemia, and several reports indicated that hyperkalaemia is usually associated with renal disorder (Geor 2007, Toribio 2007). Because the patients in groups 1 and 2 were treated with lactated ringer's solution, the serum $\mathrm{Na}$ and $\mathrm{K}$ were within normal range in these groups, what indicates that these NSAIDs may have no effects on serum $\mathrm{Na}$ and $\mathrm{K}$, despite their effects on FENa and FEK. The NSAIDs used did not influence the reabsorption of inorganic phosphate in the proximal tubules, because the FEiP were not increased in all groups compared to control group. Some horses of group 2 developed a mild to moderate form of hypomagnesaemia in comparison with the control group, but still within the reference range, which, in combination with a mildly increased FEMg and reduced U-Cr:S-Cr ratio, suggests that using $M Z$ may slightly reduce the reabsorption of

\begin{tabular}{|c|c|c|c|c|}
\hline Variables & Control group $(n=30)$ & $\begin{array}{l}\text { Group } 1(\mathrm{n}=7) \\
\text { Flunixin meglumine }\end{array}$ & $\begin{array}{l}\text { Group } 2(n=6) \\
\text { Metamizole }\end{array}$ & $\begin{array}{l}\text { Group } 3(n=7) \\
\text { Phenylbutazone }\end{array}$ \\
\hline Mucus (g/L) & $1.30(0.84-1.56)$ & $0.77(0.46-1.39)$ & $0.60(0.41-1.69)$ & $1.56(0.73-2.54)$ \\
\hline Mucus: $U-C r(\mathrm{~g} / \mathrm{mmol})$ & $0.05(0.04-0.06)$ & $0.05(0.04-0.06)$ & $0.06(0.03-0.14)$ & $0.07(0.07-0.09)^{*}$ \\
\hline
\end{tabular}

Table 5 Urinary IgA concentrations and IgA:U-Cr ratios of the healthy horses (control group) and groups treated (group 1: horses treated with flunixin meglumine for three days; group 2: horses treated with metamizole for three days; group 3: horses treated with phenylbutazone for three to five days). The results are described as median, $\left(1^{\text {st }}\right.$ to $3^{\text {rd }}$ quartile). $n$, number of horses in each group. *Significantly different values compared to those of control group.

\begin{tabular}{ccccc}
\hline Variables & Control group $(\mathrm{n}=30)$ & $\begin{array}{c}\text { Group } 1(\mathrm{n}=7) \\
\text { Flunixin meglumine }\end{array}$ & $\begin{array}{c}\text { Group 2 }(\mathrm{n}=6) \\
\text { Metamizole }\end{array}$ & $\begin{array}{c}\text { Group 3 }(\mathrm{n}=7) \\
\text { Phenylbutazone }\end{array}$ \\
\hline $\lg \mathrm{A}(\mathrm{gg} / \mathrm{L})$ & $139.8(37.4-371.7)$ & $515.8(244.8-576.3)^{*}$ & $381.5(107.6-972.5)$ & $49.5(8.0-481.8)$ \\
$\lg \mathrm{A}: \mathrm{U}-\mathrm{Cr}(\mathrm{gg} / \mathrm{mmol})$ & $5.3(1.8-16.7)$ & $26.0(17.9-62.0)^{*}$ & $27.0(8.9-77.6)^{*}$ & $4.6(0.2-29.9)$ \\
\hline
\end{tabular}


Mg at the thick ascending loop of Henle, although FEMg in this group is not significantly different from the control group. It has been reported that 50 to $70 \%$ of the $\mathrm{Mg}$ in horses is reabsorbed in the thick ascending loop of Henle (Toribio 2007). Normal S-Cr, glucose, total protein and BUN concentrations of all groups (compared to the control group) indicate that renal side effects caused by FM, MZ and PHZ cannot be detected using these serum biochemical parameters on the third or until the fifth day of administrations. A previous study, in which $\mathrm{PHZ}$ was used at a dose of $4.4 \mathrm{mg} / \mathrm{kg}$, i.v., Q8h, for 12 days, reported that using PHZ for 8 days caused significant hypoproteinaemia and hypoalbuminaemia, and further use of $\mathrm{PHZ}$ up to 12 days caused even more reduction in serum total protein and albumin concentrations, whereas FM had no effects on equine serum protein concentrations (MacAllister et al. 1993). The difference from our study is that the PHZ dose was used three times a day and length of treatment was longer in the latter study, which suggests that prolonged and more frequent usage of $\mathrm{PHZ}$ can lead to proteinlosing nephropathy. Urinary specific gravity is affected by the concentration of the solutes in the urine. Decreased concentrations of UUN, U-Cr, K, Ca and $\mathrm{Cl}$ in group 2 caused a urine specific gravity less than 1.035 (control group), however, $\mathrm{MZ}$ does not cause polyuria, but the horses with colic treated with laxatives could have more water intake after resolving the impaction (Spallek et al. 2011). Therefore, group 2 showed significantly decreased urinary $\mathrm{FENa}$, which is probably a renal compensatory mechanism. The FECl and FEK were significantly decreased in group 2, which could be influenced by the laxative treatment with sodium sulphate (1.8\%) (Spallek et al. 2011 ). The loop of Henle controls urine concentration via a countercurrent multiplication mechanism, which depends mainly on concentrations of urea and sodium salts in the renal medullary interstitial fluids (Sadowski and Dobrowolski 2003, Schott 2010). In the present study, both U-Cr and UUN concentrations were significantly lower in both groups 1 and 2 than in the control group. This could be partially because of the slightly low BUN concentrations of these two groups, which could be due, in turn, to the i.v. fluid treatment (group 1) and more water intake (group 2) rather than loop of Henle dysfunction. Using PHZ did not affect the UUN concentration, however, it caused a significant increase of FECa and FEMg in comparison with the control group, which suggests that using of $\mathrm{PHZ}$ in horses with orthopaedic pain can affect the reabsorption of $\mathrm{Ca}$ and $\mathrm{Mg}$ at the thick ascending loop of Henle. Previous studies pointed to renal crest necrosis as a side effect of using $\mathrm{PHZ}$, since the $\mathrm{PHZ}$ can cause inadequate blood supply in the renal medulla in waterdeprived horses (Gunson and Soma 1983, MacAllister 1993). However, the difference between the latter studies and our study is that, unlike these two studies, the horses in group 3 of our study were hydrated (as their PCV showed), and these horses were administered the recommended dose of $\mathrm{PHZ}$. The dosage of $\mathrm{PHZ}$ used caused a high-grade increase of the U-GGT:U-Cr ratio in group 3 in comparison with the control group, but it is still within the normal range and does not indicate a damaging effect on brush border cells of the renal proximal tubular epithelium. Only a high U-Pro:U-Cr ratio can be used to detect glomerular or tubular dysfunction. The UPro: $\mathrm{U}-\mathrm{Cr}$ ratio of group 1 and 2 were significantly increased compared with the control group, which suggests a mild tubular dysfunction. Our results suggest that the concentration of the 3rd quartile of the urine protein was higher than the normal range only in group 1 (FM). In an experimental study to investigate the effect of daily FM administration for five days on clinical and clinicopathological parameters in foals, the FM did not affect the PCV in the foals treated (Carrick et al. 1989). One of the side effects of $\mathrm{PHZ}$ in horses is anorexia; as the horses treated with $\mathrm{PHZ}$ become anorectic, they drink inadequate amounts of water, which causes the urine to be concentrated, which appeared in the specific gravity of the urine in this group compared with the control group. This suggestion is consistent with another report that $\mathrm{PHZ}$ can cause anorexia in the horses treated and subsequent progressive hypercreatininaemia (MacKay et al. 1983). However, horses treated with $\mathrm{PHZ}$ in this study were not anorectic and had no hypercreatininaemia. Horses in groups 1 and 2 showed no significantly decreased medians of urinary mucus concentrations, however, their mucus: $\mathrm{U}-\mathrm{Cr}$ ratios were within the same range compared with the control group. Horse's urine is rich in mucus, mainly to prevent the formation of urinary stones and subsequent UTIs. A significant increase in the $\lg \mathrm{A}: \mathrm{U}-\mathrm{Cr}$ ratios of the horses in groups 1 and 2 has been observed in this study. Mucosal $\lg A$ is secreted by B lymphocytes, then transported through epithelial cells into the organs' lumen due to mucosal stimulation (Tezuka et al., 2007, Lewis et al. 2010). The increased urinary IgA concentrations in both groups 1 and 2 could be caused by the influence of FM or MZ on the function of the proximal tubules.

\section{Conclusion}

The current study illustrates effects of commonly used NSAIDs on kidney functions, urinary mucus, and $\lg A$ secretions in horses. Parameters such as U-Pro:U-Cr and U-GGT:U-Cr ratios and FEMg, in combination with other clinical and clinicopathological values, can be used to detect dysfunction caused by $F M, M Z$ and $\mathrm{PHZ}$ in the renal proximal tubules and the loop of Henle in equine kidneys. The renal pelvis can increase urinary mucus secretion, presumably as a preventive mechanism against the necrotic effect of $\mathrm{PHZ}$ in the adjacent renal papillae. Different possibilities could be attributed to the elevated urinary $\lg$ A secretion, due to glomerular and tubular inflammatory reaction or leaked through damaged renal glomeruli, therefore, further investigations regarding urinary immune responses are required.

\section{Acknowledgment}

The authors would like to thank Ms. Annekathrin Ruhland, Ms. Carola Näther and Ms. Julia Schwippel, technicians at the Clinical Pathological Laboratory, Department of Large Animal Medicine, Faculty of Veterinary Medicine, Leipzig University, for their technical assistance.

\section{Manufacturers' addresses}

a Co. Sigma-Aldrich, Taufkirchen, Bavaria, Germany.

b Co. Beckman-Coulter, Krefeld, Nordrhein-Westfalen, Germany.

c Kamiya Biochemical Company, Seattle, Washington, USA.

d Thermo Fischer Scientific, Erlangen, Bavaria, Germany. 
e International Business Machines (IBM) cooperation, New York, USA

\section{References}

Aleman M., Nieto J., Higgins J. (2011) Ulcerative cystitis associated with phenylbutazone administration in two horses. J. Am. Vet. Med. Assoc. 239, 499-503

Bentz B. (2015) Clinical pharmacology of the equine musculoskeletal system. In: Cole C., Bentz B., Maxwell L. (eds.), Equine Pharmacology. Wiley-Blackwell, Hoboken, NJ, USA, 218-253

Björnsson S. (1993) Simultaneous preparation and quantitation of proteoglycans by precipitation with Alcian blue. Anal. Biochem. 210, 282-291

Björnsson S. (1998) Quantitation of proteoglycans as glycosaminoglycans in biological fluids using an Alcian blue dot blot analysis. Anal. Biochem. 256, 229-237

Brobst D., Parry B. (1987) Appendices: Normal clinical pathology data. In: Robinson E. (ed), Current Therapy in Equine Medicine. Saunders, Philadelphia, PA, 725-734

Carrick J., Papich M., Middleton D., Naylor J., Townsend H. (1989) Clinical and pathological effects of flunixin meglumine administration to neonatal foals. Can. J. Vet. Res. 53, 195-201

Cook V., Blikslager A. (2015) The use of nonsteroidal anti-inflammatory drugs in critically ill horses. J. Vet. Emerg. Crit. Care 25, 7688

Corley K., Stephen J. (2008) Appendix. In: Corley K., Stephen J. (eds), The Equine Hospital Manual. Blackwell Publishing Ltd., Oxford, United Kingdom, 654-688

Deo S., Vaidya A. (2004) Elevated levels of secretory immunoglobu$\operatorname{lin} A(\operatorname{slg} A)$ in urinary tract infections. Indian J. Pediatr. 71, 37-40

El-Ashker M., Hussein H., El-Sebaei M. (2012) Evaluation of urinary variables as diagnostic indicators of acute kidney injury in Egyptian draft horses treated with phenylbutazone therapy. J. Equine Vet. Sci. 32, 268-273

Geor R. J. (2007) Acute renal failure in horses. Vet. Clin. Equine 23, 577-591

Gunson D., Soma L. (1983) Renal papillary necrosis in horses after phenylbutazone and water deprivation. Vet. Pathol. 20, 603-610

Halbmayr T. (1999) Quantitative and qualitative urinary protein excretion in healthy and sick horses. Doctoral Thesis, Faculty of Veterinary Medicine, University of Leipzig

Hansson G. (2012) Role of mucus layers in gut infection and inflammation. Curr. Opin. Microbiol. 15, 57-62

Harirforoosh S., Jamali F. (2009) Renal adverse effects of nonsteroidal anti-inflammatory drugs. Expert. Opin. Drug Saf. 8, 669-681

Jasiecke A., Maslanka T., Jaroszewski J. (2014) Pharmacological characteristics of metamizole. Pol. J. Vet. Sci. 17, 207-214

Köller G., Gieseler T., Schusser G. (2014) Hematology and serum biochemistry reference ranges of horses of different breeds and age measured with newest clinicopathological methods. Pferdeheilkunde 30, 381-393

Köller G., Recknagel S., Spallek A., Brever J., Schusser G. (2010) Concentration of mucus in gastric juice in normal adult horses withhold feed and after oral application of Pronutrin ${ }^{\circledR}$. Pferdeheilkunde 26, 186-190

KuKanich B., Bidgood T., Knesl O. (2012) Clinical pharmacology of nonsteroidal anti-inflammatory drugs in dogs. Vet. Anaesth. Analg. 39, 69-90

Lascelles B., Court M., Hardie E., Robertson S. (2007) Nonsteroidal anti-inflammatory drugs in cats: a review. Vet. Anaesth. Analg. 34, 228-250

Lewis M., Wagner B., Irvine R., Woof J. (2010) IgA in the horse: cloning of equine polymeric Ig receptor and $J$ chain and characterization of recombinant forms of equine IgA. Mucosal Immunol. 3, 610-621

MacAllister C., Morgan S., Borne A., Pollet R. (1993) Comparison of adverse effects of phenylbutazone, flunixin meglumine, and ketoprofen in horses. J. Am. Vet. Med. Assoc. 202, 71-77

McConnico R., Morgan T., Williams C., Hubert J., Moore R. (2008) Pathophysiologic effects of phenylbutazone on the right dorsal colon in horses. Am. J. Vet. Res. 69, 1496-1505

MacKay R., French T., Nguyen H., Mayhew I. (1983) Effects of large doses of phenylbutazone administration to horses. Am. J. Vet. Res. 44, 774-780

Matyjaszek S. A., Morton A. J., Freeman D. E., Grosche A., Polyak M. M. R., Kuck H. (2009) Effects of flunixin meglumine on recovery of colonic mucosa from ischemia in horses. Am. J. Vet. Res. 70, 236-246

Nieto J., Aleman M., Anderson J., Fiack C., Snyder J. (2012) effects of phenylbutazone on gene expression of cyclooxygenase- 1 and 2 in the oral, glandular gastric, and bladder mucosae of healthy horses. Am. J. Vet. Res. 73, 98-104

Sadowski J., Dobrowolski L. (2003) The renal medullary interstitium: focus on osmotic hypertonicity. Clin. Exp. Pharmacol. Physiol. 30, $119-126$

Saulez M., Cebra C., Heidel J., Walker R., Singh R., Bird K. (2005) Encrusted cystitis secondary to Corynebacterium matruchotii infection in a horse. J. Am. Vet. Med. Assoc. 226, 246-248

Schaer B., Orsini J. (2014), Urinary system. In: Orsini J., Divers T. (eds.), Equine Emergencies: Treatment and Procedures, 4th ed. Elsevier Saunders, St. Louis, MO, USA, 485-496

Schott H. (2010) Examination of the urinary system. In: Reed S., Bayly W., Sellon D. (eds.), Equine Internal Medicine, 3rd ed. Elsevier Saunders, St. Louis, MO, USA, 1162-1176

Squinas, S. Britton A. (2013) An unusual case of urinary retention and ulcerative cystitis in a horse, sequelae of pelvic abscessation, and adhesions. Can. Vet. J. 54, 690-692

Spallek A., Brever J., Recknagel S., Köller G., Schusser G. (2011) Influence of laxatives on electrolyte and water balance in normal horses. Pferdeheilkunde 27, 487-494

Tezuka H., Abe Y., Iwata M., Takeuchi H., Ishikawa H., Matsushita M., Shiohara T., Akira S., Ohteki T. (2007) Regulation of IgA production by naturally occurring TNF/iNOS-producing dendritic cells. Nature. 448, 929-933

Tomlinson J., Blikslager A. (2004) Effects of ischemia and the cyclooxygenase inhibitor flunixin on in vitro passage of lipopolysaccharide across equine jejunum. Am. J. Vet. Res. 65, 1377-1383

Toribio R. (2007) Essential of equine renal and urinary tract physiology. Vet. Clin. Equine 23, 533-561

Erweiterte Zusammenfassung

\section{Auswirkungen von Flunixin Meglumin, Metamizol und Phenylbutazon auf die Nierenfunktion, die Mukuskon- zentration im Urin und die sekretorische Immunglobulin A $(\lg \mathrm{A})$-Konzentration}

Nichtsteroidale anti-inflammatorische Medikamente (NSAIDs) werden in der Pferdemedizin oft eingesetzt. Beim Pferd treten unterschiedliche unerwünschte Arzneimittelwirkungen in erster Linie den Gastrointestinaltrakt(GI) und die Niere betreffend auf. Der Wirkmechanismus der NSAIDs beruht auf der Inhibition von COX-1 und COX-2, Enzyme welche für die Synthese von Prostanoiden verantwortlich sind. Letztere sind für die Prävention von Magenulzera von Bedeutung, unterstützen die Reparaturvorgänge der Magenschleimhaut und sie kontrollieren und halten den Blutfluss in GI und Niere aufrecht, um eine etwaige Hypovolämie zu korrigieren. Unterschiedliche Untersuchungen haben sich mit den Auswirkungen der NSAIDs auf den GI einschließlich des Auftretens von Magenulzera, der Right Dorsal Colitis und Durchfall beim Fohlen beschäftigt. Nur wenige Studien befassten sich mit den Auswirkungen auf Niere und Blase. Es besteht die Möglichkeit, dass bei einer Phenylbutazonüberdosierung eine renale 
papilläre Nekrose entsteht. Auch Metamizol ist in der Lage die renale Funktion negativ zu beeinflussen. Um die Auswirkungen von NSAID-Gaben auf die Nierenfunktion zu beurteilen, werden das Gammaglutamytrans-ferase (GGT)-zum Kreatinin-Verhältnis im Urin erfasst sowie die fraktionelle Exkretion von Natrium berechnet. Für den Abwehrmechanismus des Urogenitaltraktes sind der Mukus im Urin und sekretorisches Immunglobulin A von Bedeutung, beide verhindern die Anheftung von Bakterien und unterstützen deren Entfernung aus dem urogenitalen Trakt. Das Ziel dieser Studie war die Beurteilung der Auswirkungen einer Flunixin Meglumin (FM), Phenylbutazon (PHZ)- sowie Metamizol (MZ)-Gabe auf unterschiedliche Nieren-Parameter sowie die Mukus- und die IgA Konzentration im Urin.

Für die Untersuchung standen dreißig Kontrollpferde mit einem Alter zwischen 2 und 24 Jahren zur Verfügung sowie 20 Tiere, welche aus unterschiedlichen Gründen mit NSAIDs therapiert wurden. Pferde der Gruppe 1 erhielten über drei Tage FM $(1,1 \mathrm{mg} / \mathrm{kg}$ LM i.v. à $12 \mathrm{~h})$ aufgrund einer Kolonverlagerung in den Milznierenraum, welche am zweiten Behandlungstag rektal nicht mehr zu palpieren war, parallel wurden die Pferde entsprechend des berechneten intravaskulären Volumendefizit infundiert. Pferde der Gruppe 2 erhielten über drei Tage aufgrund einer Obstipation des linken ventralen Kolonlängslage Metamizol $(40 \mathrm{mg} / \mathrm{kg}$ LM i.v. à 12) und zusätzlich per Nasenschlundsonde eine isotone Natiumsulfatlösung (1,8\%, $20 \mathrm{ml} / \mathrm{kg}$ LM/ Tag). Die Obstipation war nach $48 \mathrm{~h}$ rektal nicht mehr zu palpieren. Pferde mit einer Lahmheit (Grad 1/5) erhielten PHZ (4,4 mg/kg LM oral à $24 \mathrm{~h}$ für 3-5 Tage). Blut- und Urinproben wurden bei den Pferden der Gruppen 1 und 2 am dritten Behandlungstag genommen und bei Tieren der Gruppe 3 an den Tagen drei bis fünf. Es folgte die Bestimmung der $\mathrm{Na}-, \mathrm{Cl}_{-}, \mathrm{K}-, \mathrm{Mg}-$, $\mathrm{Ca}-$ und iP-Konzentrationen im Serum, der Konzentration von Blutharnstoff, Kreatinin, Glukose und von Gesamteiweiß (Pro). Im Urin wurde der pH-Wert sowie die Dichte erfasst und die Konzen- trationen der Elektrolyte, des Kreatinins, Harnstoffes, der Glukose, des Eiweißes sowie die Aktivität der GGT bestimmt und die fraktionelle Exkretion(FE) berechnet. Des Weiteren erfolgte die Bestimmung der IgA-Konzentration im Urin sowie vom Mukus und diese Werte wurden ins Verhältnis zum Kreatininwert im Urin gesetzt.

Der überwiegende Teil der biochemischen Serum-Parameter differierten nicht signifikant zwischen den Tieren der Kontrollgruppe und den behandelten Pferden. Bei Pferden der Gruppe 2 waren die Serummagnesiumkonzentration signifikant niedriger. Bei diesen Pferden war auch die spezifische Dichte des Urins signifikant niedriger. Bei Pferden der Gruppe 1 und 2 war die Eiweißkonzentration im Urin signifikant höher. Pferde, welche Flunixin oder PHZ erhalten hatten, wiesen einen signifikante höheren FENa-Wert auf und Tiere der Gruppe 2 einen niedrigeren. $\mathrm{FECl}$ war bei diesen Pferden signifikant niedriger ebenso wie FEK. Ein Anstieg von FECa und FEMg wurde nach der Behandlung mit PHZ festgestellt. Bei diesen Pferden war das U-GGT: U-Cr-Verhältnis signifikant höher. Bei Pferden der Gruppen 1 und 2 waren im Vergleich zu den Kontrollwerten das Verhältnis U-Pro: U-Cre signifikant höher und das Verhältnis U-Cr: S-Cr signifikant niedriger. In Hinblick auf das Verhältnis Urin Mukus: UCr konnte nur bei Pferden, welche $\mathrm{PHZ}$ erhalten hatten, ein signifikanter Unterschied zu den Kontrollwerten nachvollzogen werden. Die IgA Konzentration im Urin im Verhältnis zu U-Cre war bei Pferden der Gruppe 1 und 2 signifikant höher. Die Ergebnisse zeigen, dass die Langzeitanwendung von $\mathrm{PHZ}$ einen Einfluss auf den aufsteigenden Schenkel der Henle Schleife hat und alle untersuchten NSAIDs einen Einfluss auf die proximalen Tubuli haben können. Des Weiteren verursachte Phenylbutazon einen Anstieg der Mukus-Sekretion im Urin. Dies stellt wahrscheinlich einen protektiven Mechanismus in Hinblick auf den nekrotischen Effekt von PHZ dar. Die Ergebnisse zeigen, dass Parameter wie U-Pro: U-Cr, U-GGT: U-Cr und FEMg hilfreich für die Erfassung dieser renalen Veränderungen sind. 